\title{
PERBANDINGAN BESARAN SFERIKAL EKUIVALEN BERDASARKAN METODE PENGUKURAN VISUS SUBJEKTIF DAN OBJEKTIF PENDERITA AMETROPIA PADA MAHASISWA FAKULTAS KEDOKTERAN UNIVERSITAS SAM RATULANGI
}

\author{
${ }^{1}$ Rezky Palangi \\ ${ }^{2}$ Fransisca Lintong \\ ${ }^{2}$ Maya Moningka \\ ${ }^{1}$ Bagian Fisika Fakultas Kedokteran Universitas Sam Ratulangi Manado \\ ${ }^{2}$ Bagian Anatomi-Histologi Fakultas Kedokteran Universitas Sam Ratulangi Manado
}

\begin{abstract}
Ametropia or refractive error of the eye is the case almost every time we encounter in our environment and increasing steadily each year. One of the factors why refractive error often are not fully corrected due to the difference in the value of spherical and cylindrical or spherical equivalent between the examination of subjective and objective visual acuity. This study aims to determine the difference of the results of subjective and objective visual acuity at patiens ametropia. Analytical research methods with cross sectional design. The subjects were taken from a population that is 40 people. Selected subjects who met the inclusion criteria ; suffering that can be in a correction of ametropia with refractive lenses, suffer ametropia in one eye or both and are willing to be examined. The results obtained are very significant differences in spherical equivalent subjective and objective examination of patients with abnormalities of refraction of-0.8D on the right and left eye of the subject. With more negative value of objective examination. By doing so required a certain effort of medical personnel to maximize the refractive examinations on patients in order to minimize the error correction of ametropia. Conclusion: There is differences in spherical equivalent subjective and objective examination.
\end{abstract}

Keywords: spherical equivalent, subjective vision, objective vision

\begin{abstract}
Abstrak: Ametropia atau kelainan refraksi mata merupakan kasus yang hampir setiap saat kita jumpai di lingkungan sekitar kita dan meningkat terus setiap tahunnya. Salah satu faktor mengapa kelainan refraksi sering dikoreksi secara tidak penuh akibat perbedaan nilai sferis dan silinder ataupun sferikal ekuivalen antara hasil pemeriksaan visus subjektif dan objektif. Penelitian ini bertujuan untuk mengetahui perbedaan dari hasil pemeriksaan visus subjektif dan objektif pada penderita ametropia. Metode penelitian analitik dengan desain potong lintang. Subyek diambil dari populasi yang ada sejumlah 40 orang. Subyek dipilih yang memenuhi kriteria inklusi, yaitu; menderita ametropia yang dapat di koreksi dengan lensa bias, menderita ametropia pada salah satu mata atau keduanya dan bersedia untuk diperiksa. Hasil yang didapatkan perbedaan sferikal ekuivalen sangat bermakna pada pemeriksaan subjektif dan objektif penderita kelainan refraksi sebesar - $0.8 \mathrm{D}$ pada mata kanan dan kiri subyek. Dengan nilai pemeriksaan objektif lebih negatif. Dengan begitu diperlukan upaya tertentu dari tenaga medis untuk memaksimalkan pemeriksaan kelainan refraksi pada penderita ametropia agar meminimalkan kesalahan koreksi. Simpulan: terdapat perbandingan besaran sferikal ekuivalen antara pemeriksaan visus subjektif dan objektif.
\end{abstract}

Kata kunci: Sferikal Ekuivalen, visus subjektif, visus objektif 
Ametropia atau kelainan refraksi mata merupakan kasus yang hampir setiap saat kita jumpai di lingkungan sekitar kita dan meningkat terus tiap tahunnya. Kelainan refraksi dikenal dalam bentuk miopia, hipermetropia dan astigmatigma. ${ }^{1}$ Beberapa faktor yang dapat mempengaruhi kelainan refraksi antara lain genetik, umur, jenis kelamin, ras dan lingkungan. Pengaruh genetik terhadap pasanganpasangan kembar yang tinggal di lingkungan yang berbeda memiliki pengaruh besar pada miopia dan hipermetropia. $^{2}$

WHO menyatakan $80 \%$ tunanetra dapat dicegah. Namun WHO juga mencatat ternyata dari 6697 juta orang populasi dunia sekitar 4,3\% atau 285 juta orang mengalami tunanetra. Dari 4,3\% yang mengalami tunanetra sekitar 14\% atau 39 juta orang mengalami kebutaan dan sekitar 86\% atau 246 juta orang mengalami kelemahan penglihatan sedangberat. Kelemahan penglihatan sedangberat $42 \%$ diakibatkan oleh kesalahan koreksi pada penderita kelainan refraksi. ${ }^{3}$ Studi telah melaporkan prevalensi kelainan refraksi setiap negara di dunia berkisar antara $1 \%$ sampai $11 \%{ }^{4-6}$

Kesalahan koreksi mempengaruhi segala usia dan kelompok etnis. Kesalahan koreksi merupakan penyebab utama gangguan penglihatan yang mengakibatkan hilangnya kesempatan dalam pendidikan dan pekerjaan, juga mengakibatkan produktivitas dan kualitas hidup yang rendah. ${ }^{3}$ Banyak anak memiliki kelainan refraksi yang makin memburuk akibat diagnosis yang keliru atau akibat dari kesalahan koreksi pada penderita yang mengalami kelainan refraksi. ${ }^{7}$

Pada umumnya penderita yang mengalami kelainan refraksi dikoreksi dengan lensa bulat yang dapat diperoleh dengan harga yang murah. Lensa bulat tersebut jarang yang memiliki lensa silinder yang sebenarnya dibutuhkan penderita kelainan refraksi jenis astimatigma. Pengujian ketajaman visual sangat penting dalam mengoreksi kelainan refraksi. Setiap mata harus diperiksa secara terpisah untuk memastikan bahwa kartu tes (Snellen Chart) telah dibaca sejauh mungkin dan orang yang diperiksa tidak hanya berhenti ketika membaca di huruf kecil. Seringkali penderita akan berpikir bahwa ini adalah kacamata dan akan berusaha lebih keras, inilah yang dikenal dengan pemeriksaan subjektif. ${ }^{8}$

Metode objektif seperti retinoscopy dan autorefraksi juga dapat menentukan kelainan refraksi mata. Teknik ini dapat memberikan cara yang cepat, tepat dan dapat diandalkan untuk mengukur kelainan refraksi bila dilakukan oleh pemeriksa yang berpengalaman. Banyak ditemukan perbedaan sistematis dalam kesalahan bias yang ditentukan dari hasil retinoscopy dan refraksi subjektif. ${ }^{9}$ Pengukuran sferikal ekuivalen pada pemeriksaan autorefraksi telah dilaporkan merupakan suatu hal yang valid dan reliabel. ${ }^{10}$ Hampir semua studi yang telah menghitung korelasi antara sferis dan silinder menggunakan sferikal ekuivalen sebagai analisis refraksi mata. ${ }^{11}$

Mengingat semakin banyak penggunaan kacamata untuk koreksi kelainan refraksi, maka penulis tertarik untuk mengetahui perbandingan besaran sferikal equivalen dari hasil pemeriksaan subjektif dan objektif pada penderita ametropia.

\section{HIPOTESIS}

1. $\mathrm{H}_{0}$ : Tidak terdapat perbandingan besaran sferikal ekuivalen berdasarkan metode pengukuran visus subjektif dan objektif pada penderita ametropia.

2. $\mathrm{H}_{1}$ : Terdapat perbandingan besaran sferikal ekuivalen berdasarkan metode pengukuran visus subjektif dan objektif pada penderita ametropia.

\section{Pemeriksaan Refraksi}

Pemeriksaan objektif dengan menggunakan alat autorefraksi. Autorefraksi memungkinkan dokter untuk melakukan pemeriksaan objektif. Alat ini 
dapat menentukan kesalahan bias sferis dan silinder, menentukan silinder yang teratur atau tidak teratur. Ketika pemeriksa menggunakan lensa koreksi yang sesuai (baik dengan lensa longgar atau phoropter), refleks autorfraksi dapat dinetralkan. Dengan kata lain, ketika pemeriksa mengarahkan pasien jauh ke lubang intip, seluruh pupil pasien diterangi dan refleks tidak akan bergerak. kekuatan lensa koreksi yang menetralkan reflekslah yang memberikan ukuran kesalahan bias pasien. ${ }^{18}$ Snellen Chart standar digunakan untuk menentukan tajam penglihatan atau

kemampuan melihat seseorang. Trial and Error untuk menentukan kekuatan lensa konkaf atau konveks yang diperlukan seseorang untuk penglihatan jelas. Dengan cara yaitu mula-mula meletakkan sebuah lensa kuat dan kemudian diganti dengan lensa yang lebih kuat atau lebih lemah sampai diperoleh lensa yang memberikan tajam penglihatan terbaik menurut pasien sendiri. $^{22}$

\section{METODOLOGI PENELITIAN}

Penelitian dilakukan di Bagian Poliklinik Mata RS. Prof. DR. R. D Kandou, selama Desember 2014. Desain penelitian yang digunakan adalah analitik deskriptif dengan pendekatan cross sectional. Populasi target adalah seluruh mahasiswa yang menderitaametropia. Sedangkan populasi terjangkau adalah seluruh mahasiswa angkatan 2010 dan 2012 yang menderita ametropia. Subyek penelitian memenuhi kriteria inklusi; Setiap mahasiswa yang menderita ametropia pada salah satu mata atau keduanya, dapat di koreksi dengan lensa bias dan bersedia untuk diperiksa. Alur penelitian adalah; 1) Penyediaan alat dan bahan, 2) Observasi populasi 3) menentukan kriteria inklusi dan eksklusi 4) menetukan sampel 5) melakukan pemeriksaan subjektif dan objektif 6) mengelolah data 7) menganalisis data 8) memberikan pembahasan dari hasil penelitian 9) mengambil kesimpulan dan 10) memberikan saran.

\section{HASIL PENELITIAN}

\section{Karakteristik Responden}

\section{Jenis Kelamin}

Secara keseluruhan responden perempuan (60\%) lebih banyak daripada responden laki-laki (40\%).

\section{Tabel 1. Responden berdasarkan jenis kelamin}

\begin{tabular}{ccc}
\hline $\begin{array}{c}\text { Jenis } \\
\text { Kelamin }\end{array}$ & Frekuensi & Persen \\
\hline Laki-laki & 16 & $40 \%$ \\
Perempuan & 24 & $60 \%$ \\
\hline
\end{tabular}

Umur

Secara keseluruhan umur ke-40 responden terbanyak ada pada umur 21 tahun (30\%), sedangkan yang paling sedikit pada umur 17 tahun (5\%).

Tabel 2. Responden berdasarkan umur

\begin{tabular}{ccc}
\hline Umur & Frekuensi & Persen(\%) \\
\hline 17 & 2 & $5 \%$ \\
18 & 6 & $15 \%$ \\
19 & 11 & $27,5 \%$ \\
20 & 9 & $22,5 \%$ \\
21 & 12 & $30 \%$ \\
\hline
\end{tabular}

Pengujian Hipotesis

\section{Pemeriksaan mata kanan}

Hasil penelitian memaparkan tentang analisis perbandingan besaran sferikal ekuivalen berdasarkan hasil pemeriksaaan subjektif dan objektif mata kanan dengan hasil yaitu didapatkan nilai $\mathrm{p}=0,00$ yang berarti Ho ditolak. Jadi dapat disimpulkan bahwa ada perbandingan antara besaran sferikal ekuivalen hasil pemeriksaan subjektif dan objektif pada mata kanan, karena signifikansi $(0,00<0,05)$ maka $\mathrm{H}_{1}$ diterima. 
Tabel 3. Pemeriksaan subjektif dan objektif mata kanan

\begin{tabular}{lccc}
\hline Pemeriksaan & Rata-rata & P & $\begin{array}{c}\text { Kesimpul } \\
\text { an }\end{array}$ \\
\hline $\begin{array}{l}\text { Sferikal } \\
\text { ekuivalen }\end{array}$ & $-1,9563$ & & \\
$\begin{array}{l}\text { hasil } \\
\text { pemeriksaan }\end{array}$ & & 0,00 & $\begin{array}{l}\text { Sangat } \\
\text { bermakna }\end{array}$ \\
$\begin{array}{l}\text { subjektif } \\
\text { mata kiri }\end{array}$ & & \\
\hline $\begin{array}{l}\text { sferikal } \\
\text { ekuivalen }\end{array}$ & & \\
$\begin{array}{l}\text { hasil } \\
\text { pemeriksaan } \\
\text { objektif mata } \\
\text { kiri }\end{array}$ & $-2,7594$ & & \\
\hline
\end{tabular}

\section{Pemeriksaan mata kiri}

Hasil penelitian memaparkan tentang analisis perbandingan besaran sferikal ekuivalen berdasarkan hasil pemeriksaaan subjektif dan objektif mata kiri dengan hasil yaitu didapatkan nilai $\mathrm{p}=0,00$ yang berarti Ho ditolak. Jadi dapat disimpulkan bahwa ada perbandingan antara besaran sferikal ekuivalen hasil pemeriksaan subjektif dan objektif pada mata kiri, karena signifikansi $(0,00<0,05)$ maka $\mathrm{H}_{1}$ diterima.

Tabel 4. Pemeriksaan subjektif dan objektif mata kiri

\begin{tabular}{lccc}
\hline Pemeriksaan & Rata-rata & P & $\begin{array}{c}\text { Kesimpul } \\
\text { an }\end{array}$ \\
\hline $\begin{array}{l}\text { Sferikal } \\
\text { ekuivalen }\end{array}$ & $-2,0969$ & & \\
$\begin{array}{l}\text { hasil } \\
\text { pemeriksaan }\end{array}$ & & 0,00 & $\begin{array}{l}\text { Sangat } \\
\text { bermakna }\end{array}$ \\
$\begin{array}{l}\text { subjektif } \\
\text { mata kanan }\end{array}$ & & \\
\hline $\begin{array}{l}\text { sferikal } \\
\text { ekuivalen }\end{array}$ & & & \\
$\begin{array}{l}\text { hasil } \\
\text { pemeriksaan } \\
\text { objektif mata } \\
\text { kanan }\end{array}$ & $-2,9063$ & & \\
\hline
\end{tabular}

\section{BAHASAN}

Sesuai dengan hasil penelitian secara cross sectional yang dilakukan di bagian Poliklinik Mata di RSUP Prof. Dr. R. D. Kandou Manado subjek dalam penelitian ini terdiri mahasiswa fakultas kedokteran Universitas Sam Ratulangi Manado. Total keseluruhan subjek penelitian ini adalah 40 orang dengan perbandingan laki-laki dan perempuan 2:3. Kisaran umur dalam penelitian ini 17-21 tahun dengan sebaran umur terbanyak pada umur 21 tahun (30\%) dan yang paling sedikit pada umur 17 tahun (5\%). Pendidikan subjek dalam penelitian ini adalah mahasiswa fakultas kedokteran jadi dapat diasumsikan bahwa subjek memiliki tingkat pengetahuan yang cukup mengenai kesehatan.

Penelitian tentang perbandingan antara hasil pemeriksaan objektif dan subjektif telah dilakukan oleh beberapa peneliti lain. Sebuah studi yang dilakukan di United Kingdom(UK) melaporkan bahwa perbedaan terkecil antara antara pemeriksaan objektif yang menggunakan autorefraksi (Shin-Nippon Nvision K5001) dan pemeriksaan subjektif adalah sekitar $0.14 \mathrm{D}$, dimana hasil pemeriksaan objektif memiliki nilai yang lebih negatif. $^{12}$ Dari hasil penelitian ini juga didapatkan hal yang sama bahwa 99\% pemeriksaan objektif memiliki hasil sferikal ekuivalen lebih negatif dibandingkan hasil pemeriksaan subjektif.

Penyebab terjadinya kelainan refraksi hingga saat ini secara pasti masih belum jelas. Adanya berbagai teori yang dikemukakan oleh para peneliti salah satunya adalah Eulernberg, namun Peter Pullicino menyatakan bahwa teori-teori yang diungkapkan oleh Eulenberg tidak memuaskan karena memiliki terlalu banyak variabel yang tidak bisa dikontrol. $^{1,15}$

Penelitian tentang kelainan refraksi tak terkoreksi penuh telah dilakukan oleh 
beberapa peneliti. Studi yang dilakukan di Semarang menyatakan persentasi kasus kelainan refraksi tak terkoreksi penuh dibandingkan kelainan refraksi terkoreksi penuh selama periode tahun 2002-2003 adalah 23,05\%. ${ }^{1}$ Di negara maju prevalensi kesalahan koreksi telah dilaporkan sekitar 8,2\% di Baltimore, 10,4\% di Kazuhiro (Jepang) dan 18,2\% di Santa Monica (Amerika Serikat). ${ }^{6,7}$ Data hasil penelitian ini dengan Paired Sample T-tes mendapatkan bahwa pemeriksaan subjektif dan objektif pada mata kiri dan kanan didapati perbedaan yang sangat bermakna, dimana $p$ value $(0,00)$ lebih kecil daripada nilai alpha $(0,05)$. Menurut peneliti hal inilah merupakan salah satu faktor mengapa kelainan refraksi sering dikoreksi secara tidak penuh akibat perbedaan dari hasil kedua pemeriksaan tersebut.

\section{SIMPULAN}

Terdapat perbandingan yang bermakna antara besaran sferikal ekuivalen berdasarkan metode pemeriksaan subjektif dan objektif pada mata kanan dan kiri penderita ametropia. Rata-rata hasil pemeriksaan objektif lebih negatif daripada rata-rata hasil pemeriksaan subjektif pada mata kanan dan kiri penderita ametropia.

\section{SARAN}

Diperlukan upaya tertentu dari tenaga medis untuk memaksimalkan pemeriksaan kelainan refraksi pada penderita ametropia agar meminimalkan kesalahan koreksi. Diharapkan tenaga medis dapat mengetahui adanya efek dari kesalahan koreksi atau pengabaian koreksi pada penderita kelainan refraksi. Untuk penelitian selanjutnya diharapkan dapat meneliti perbandingan sferikal ekuivalen dengan menggunakan alat pemeriksaan refraksi yang lainnya.

\section{DAFTAR PUSTAKA}

1. Hartanto W, Inakawati S. Kelainan refraksi tak terkoreksi penuh di RSUP Dr. Kariadi Semarang periode 1 Januari 2002 - 31 Desember 2003. Media Medika Muda. 2010;4:26.

2. Hammond CJ, Snieder H, Gilbert CE, Spector TD. Genes and environment in refractive error: the twin eye study. Investigative Ophthalmology and Visual Science. 2001;42(6):1232-6.

3. Pascolini D, Mariotti SP. Global Estimates of Visual Impairment: 2010. British Journal of Ophthalmology. 2011;10:1-5.

4. Worku Y, Bayu S. Screening for ocular abnormalities and subnormal vision in school children of Butajira town, Southern Ethiopia. Ethiop J Health Dev. 2002;16:165-71.

5. Wedner SH, Ross DA, Balira R, Kaji L, Foster A. Prevalence of eye diseases in primary school children in a rural area of Tanzania. $\mathrm{Br} \mathrm{J}$ Ophthalmol. 2000;84:1291-7.

6. Kawuma M, Mayeku R. A survey of the prevalence of refractive errors among children in lower primary schools in Kampala district. Afr Health Sci. 2002;2:69-72.

7. Yared AW, Balaynew WT, Destaye S, Ayanaw T, Zelalem E. Prevalence of refractive errors among school children in Gondar town Northwest Etiopia. Middle East Afr J Opthalmol. 2012;19(4):372-6.

8. Waddel K. Spherical refraction for general eye workers. Comm Eye Health Journal. 2000;13:6-7.

9. Hung LF, Ramamirthan R, Wensveen JM, Harwerth RS, Smith EL,. Objective and Subjective refractive error measurements in Monkeys. Optom Vis Sci. 2012;89(2):168-77.

10. Gwiadza J, Weber C. Comparison of spherical equivalent refraction and astigmatism measured with the three different models of autorefractors. Optom Vis Sci. 2004;81(1):56-61.

11. Guggenheim JA, Farbrother JE. The Association between spherical and 
cylindrical component powers. Optom Vis Sci. 2004;81(1):62-63.

12. Gabriel JF. Biooptik. Fisika Kedokteran. Jakarta: EGC; 1996. h. 146-53.

13. Guyton Arthur C, Hall John E. Mata: I. Sifat Optik Mata. In: Rachman Luqman Yanuar, Hartanto Huriawati, Novrianti Andita, Wulandari Nanda. 11rd ed. Jakarta: EGC; 2007. h.64250.

14. Davies LN, Mallen EA, Wollfsohn JS, Gilmartin, Bernard. Clinical evaluation of the shin-nippon NVision-K 5001/Grand Seiko WR$5100 \mathrm{~K}$ autorefractor. Optom Vis Sci. 2003;80(4):320-4.

15. Eulenberg A. The case for th preventality of myopia. International society for the enchancement of eyesight.1996;1-23. 
